\begin{tabular}{c|c|c}
\hline \hline $\begin{array}{c}\text { Vol. 470: 125-135, 2012 } \\
\text { doi: } 10.3354 / \text { meps10121 }\end{array}$ & $\begin{array}{c}\text { MARINE ECOLOGY PROGRESS SERIES } \\
\text { Mar Ecol Prog Ser }\end{array}$ & Published December 6 \\
\hline
\end{tabular}

\title{
INTRODUCTION
}

\section{Understanding the responses of ocean biota to a complex matrix of cumulative anthropogenic change}

\author{
Philip W. Boyd ${ }^{1, *}$, David A. Hutchins ${ }^{2}$ \\ ${ }^{1}$ NIWA Centre for Chemical and Physical Oceanography, Department of Chemistry, University of Otago, Dunedin 9012, \\ New Zealand \\ ${ }^{3}$ Department of Biological Sciences, University of Southern California, Los Angeles California 90089, USA
}

\begin{abstract}
Oceanic conditions are changing at an unprecedented rate, and these anthropogenically driven changes will intensify into the future. The marine biota will encounter a complex shifting matrix of simultaneous environmental changes - including temperature, $\mathrm{pH} / \mathrm{pCO}_{2}$, nutrients, light, and oxygen - which will be further compounded by concurrent regional and local anthropogenic impacts, such as altered freshwater runoff regimes or biomass harvesting. We are only beginning to grasp the complexity of these interactive changes on ocean biota. To understand the pronounced and/or nonlinear effects of cumulative environmental stresses on organismal fitness and ecosystem functioning, the marine global-change research community can profit from the large body of existing evidence from freshwater lakes or polluted aquatic systems. We explore how the complex environmental changes will affect the biota from primary producers to higher trophic levels in both nearshore and open ocean waters, and conclude by proposing new approaches to address the formidable challenges of this research field. This Theme Section on 'Biological responses in an anthropogenically modified ocean' presents a set of papers that highlights the multiplicity of factors that will alter major biogeochemical and ecological frameworks, and raises awareness of the complexities involved in disentangling the combined effects of global, regional and local anthropogenic change on marine food webs.
\end{abstract}

KEY WORDS: Climate change $\cdot$ Cumulative environmental stress $\cdot$ Biological responses

\section{Introduction}

A major challenge for oceanographers in the 21st century will be to identify, quantify and understand how the changing climate will impact ocean biota in both coastal and offshore waters. Taking up the challenge will enable scientists to make better predictions of how climate change will alter oceanic ecosystems, biogeochemistry and resources, and hence provide projections on the magnitude of changes to ecosystem services, biogeochemical feedbacks to climate change, and food security.
Evidence about the nature and extent of changes to the ocean has come from global ocean and coupled ocean-atmosphere modelling experiments (Boyd \& Doney 2002, Sarmiento et al. 2004), timeseries observations (Dore et al. 2009) and biological manipulation experiments (Riebesell et al. 2000, Boyd et al. 2008). Together, these 3 strands provide initial verification of changing oceanic conditions (Roemmich et al. 2012); and insights into how altered conditions will affect the physiological performance of biota (Hutchins et al. 2009). 
To date, the focus of manipulation experiments has been on perturbing one environmental property, such as pH (Gattuso \& Hansson 2011). These invaluable studies have helped to define the many ramifications of altering even just one component of the ocean, along with the physiological, ecological and biogeochemical consequences. However, it is increasingly evident from more complex manipulation studies that this traditional reductive approach cannot capture a truly prognostic view of future ecosystem changes. Climate-change mediated shifts in multiple environmental properties often exert non-linear and counterintuitive controls over many aspects of ocean biota (Fu et al. 2008, Rose et al. 2009a). To date, the implications of these complex changes for ocean biota remain largely uninvestigated (Boyd 2011).

Examination of freshwater, terrestrial, and ecotoxicological studies reveals a diverse literature on multiple environmental stressors from the 1980s onwards (Calow 1989), and which explore concepts such as cumulative environmental stress (Breitberg et al. 1998). Puzzlingly, with a few exceptions (Crain et al. 2008), there has been little awareness in the oceanographic community of this valuable repository of ideas and concepts, and virtually no attempts to link what marine scientists term global (climate change), regional (e.g. atmospheric pollutants) and local (e.g. point source runoff) anthropogenic 'stressors' (hereafter referred to as 'drivers', see 'Definitions' below) and their potentially combined effects on ocean biota. There is much to be learnt from this wider literature. For example, Breitberg et al. (1999) concluded that:

\begin{abstract}
While many approaches are similar to those used to examine the effects of a single stress, studying the effects of multiple stressors usually requires a more complex experimental design and/or statistical methods to separate out often subtle and interacting effects.
\end{abstract}

In the present review, we first revisit and revise the definitions used in the wider literature; summarise the main concepts from the prior research on multiple drivers; and explore the environmental heterogeneity of marine versus other systems across a range of scales. We then discuss key topics such as the differential susceptibility of organisms to environmental drivers, and current approaches to multiple driver research, before highlighting the findings of the 7 papers - from phytoplankton to higher trophic levels - that comprise this Theme Section. Finally, we advocate new approaches to help develop research into multiple drivers.
We offer this Theme Section to highlight both recent achievements and remaining gaps in our knowledge of how multiple environmental drivers may affect future marine food webs. Inevitably, there are important subjects that are not covered here, including (but not limited to) environmental effects on key groups such as heterotrophic bacteria, zooplankton, and corals, as well as emerging experimental and analytical methodologies including molecular biology. In many cases, these subjects have been addressed elsewhere (e.g. Steinberg 2012), as they are key components of our expanding knowledge of how marine biota will respond to global change.

\section{Definitions}

The literature on multiple stressors provides useful definitions, for example Calow (1989), that can be modified to better align them with the growing climate change issue.

There is a tendency to refer to alteration of environmental properties as biological 'stressors' (Breitburg et al. 1998), as the studies in the wider literature often focussed solely on detrimental effects such as acid rain. There is recent experimental evidence that climate change perturbations, such as higher oceanic $\mathrm{CO}_{2}$ concentrations, may result in beneficial effects for some organisms, e.g. diazotroph $\mathrm{N}_{2}$ fixation rates (Hutchins et al. 2007), but detrimental effects to others, e.g. coccolithophore calcification rates (Riebesell et al. 2000). Indeed, any major change in oceanic conditions will create not only 'losers', but also 'winners' who can best adapt to the altered environment (Nogales et al. 2011). Thus, the generic term 'driver' is a more accurate descriptor than 'stressor' when discussing the effects of global anthropogenic change on ocean biota. Furthermore, the terms 'synergism' and 'antagonism' are often used to describe the interplay among multiple environmental drivers (MEDs), but often their use without further qualification (see 'Synergisms and antagonisms - what we have learnt') has caused confusion. Here, we present key definitions to help clarify some of these issues:

(1) Driver-An environmental change that results in a quantifiable biological response, ranging from stress to enhancement.

(2) Stressor-An environmental change that decreases organismal fitness.

(3) Enhancer-An environmental change that increases organismal fitness. 
(4) Additive-A biotic response to 2 or more interacting factors that equates to the sum of their individual effects (sensu Folt et al. 1999).

(5) Multiplicative-A biotic response to 2 or more interacting factors which significantly exceeds the sum of their individual effects (sensu Folt et al. 1999).

(6) Synergism-A positive feedback interaction between MEDs that is multiplicative, and requires an intrinsic metric such as a quantitative measure of organismal fitness or a physiological property.

(7) Antagonism-A negative feedback interaction between MEDs that is multiplicative, and requires an intrinsic metric.

(8) Acclimation-Short-term change resulting from a physiological response at the individual organismal level (sensu Falkowski \& LaRoche 1991).

(9) Adaptation-Long-term evolutionary change resulting from natural selection at the population level (sensu Falkowski \& LaRoche 1991).

These definitions must be employed in a contextdependent manner. For example, at the cellular level they may refer to effects on processes such as gene transcription and translation, whereas at the community level they may refer to effects on biodiversity, and at the biome level to integrative properties such as major biogeographical patterns.

It is also crucial to introduce appropriate qualifiers when using these terms. The terms synergism and antagonism are potentially confusing, since it is essential to define whether they are being employed in a mechanistic- or an outcome-based sense. In other words, are they referring to mechanistic interactions between the drivers, or to the resultant net outcome for the organism? An example of the former is the antagonistic interaction between ocean acidification (OA) and warming, whereby lowered $\mathrm{CO}_{2}$ solubility at higher ocean temperatures partially offsets $\mathrm{CO}_{2}$-driven increases in OA (Hare et al. 2007). An illustrative biological outcome-based antagonism is evidence that increases in coral calcification rates due to warming could partially counter the negative effects on calcification of decreasing carbonate ion concentration due to OA (Lough \& Barnes 2000).

A related semantic issue with these terms is the need to specify whether a positive or negative connotation is intended. For example, in discussing a hypothetical antagonistic effect, $A+B=C$, a negative connotation would be if $\mathrm{C}$ is a cumulative deleterious outcome of the 2 detrimental factors $A$ and B. Crain et al. (2008) defined antagonism in this sense when examining a collation of marine experimental studies on what they termed 'multiple stressors'. However, if $\mathrm{C}$ is less detrimental (than A or B alone) to the organism because of an 'antagonism' between the 2 negative factors A and B, then the net effect is a positive one for the organism. This use of 'antagonism' was employed by Didham et al. (2007) in a study of the cumulative effects of habitat loss and invasive species.

\section{Synergisms and antagonisms - What have we learnt?}

The logistical and interpretational issues of conducting and then interpreting the findings of a study in which MEDs are manipulated (Fig. 1) make research into the cumulative influence of MEDs daunting. The potential interplay between MEDs and the likelihood of non-linearities due to amplification and/or diminution, relative to the effects of a single driver, adds greatly to the potential complexity of the study. Again, the prior literature has much to offer: Folt et al. (1999) defined antagonism and synergism and introduced the concepts of their additive and multiplicative effects. This study emphasized the difference between multiplicative effects that arise collectively from MEDs, and effects that are largely
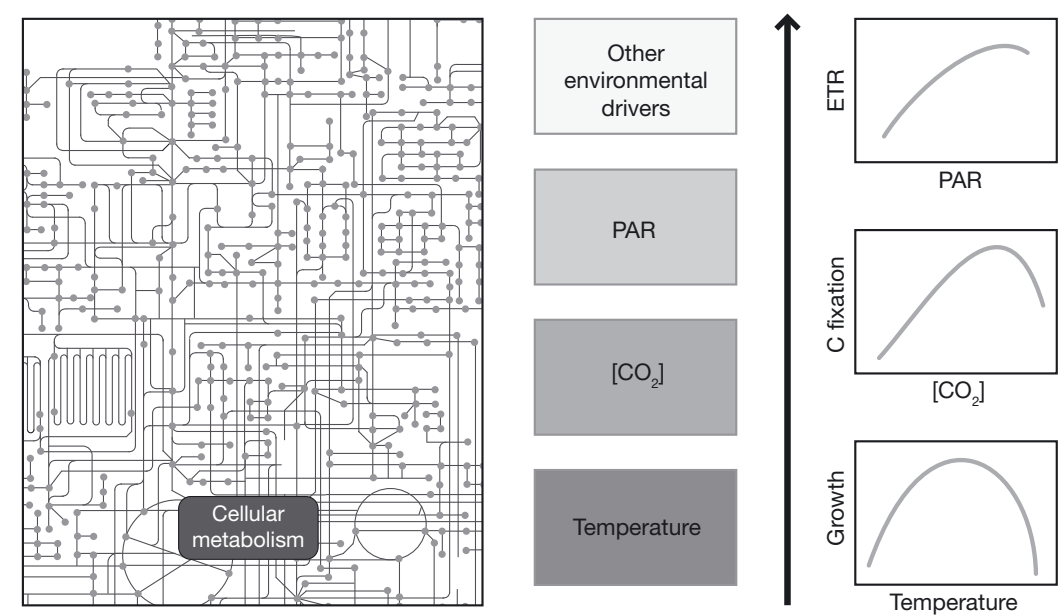

Fig. 1. Cumulative environmental stress (vertical arrow, central panels) results from both the individual and interactive effects of altered environmental conditions (central panels) on a range of the biochemical pathways (left hand panel, based on iPath, Letunic et al. 2008) of a cell, and leads to alteration of fundamental physiological processes including carbon fixation and growth (right hand panels). ETR: electron transfer rate, PAR: photosynthetically active radiation 
the result of a single over-riding driver among many. Crain et al. (2008) conducted a meta-analysis of a suite of marine studies that had investigated the biological effects of MEDs, and reported that certain experimental approaches are more likely to introduce a skew towards either an antagonism or a synergism. For example, they found that studies employing 3 stressors exhibited about twice the frequency of true synergistic outcomes compared to studies using only 2 variables. Darling \& Côté (2008) in a metaanalysis of experimental studies in which mainly 2 drivers were manipulated, reported that the incidence of synergisms and antagonisms was less than expected. Both these studies suggest that the likelihood of synergisms and antagonisms when 3 or more factors are altered could be high indeed.

\section{Environmental heterogeneity}

The effects of MEDs on biota will be influenced by environmental heterogeneity, the characteristics of the terrestrial or aquatic systems they reside in. Hence, any intercomparison of biological responses to alteration of MED properties across systems must examine their intrinsic differences. For example, the size of the open ocean and its relative isolation due to the 'buffer' of nearshore waters means that it is unlikely to be impacted by allochthonous materials such as terrestrial pollutants, compared to coastal waters and lakes. Thus, global and regional drivers as opposed to local ones will dominate in the open ocean (Fig. 2). Ocean chemistry often differs in fundamental ways from that of freshwater, e.g. carbonate chemistry in the ocean is highly buffered (Dickson 1992) and hence $\mathrm{pH}$ variability is less than in most freshwater systems (Toupin 2005, Hofmann et al. 2011). Environmental heterogeneity differs between the ocean and land, with implications for how the biota will respond to environmental change (Reusch \& Boyd in press).

The geographic realm of influence of drivers will also influence environmental heterogeneity, e.g. the overlap of global and local drivers, as this sets how many drivers are acting concurrently on the biota (Fig. 2). Our understanding of how MEDs can result in cumulative stress for the resident biota (Fig. 1) has mainly come from studies of local drivers, e.g. point source disturbances such as warming (Schiel et al. 2004). Recently, increasing awareness of the many ramifications of climate change has enhanced our knowledge of how global anthropogenic drivers, such as hypoxia, will influence the biota (Gruber 2011). However, only a few studies have considered both local and global anthropogenic drivers and their joint influence (Darling \& Côté 2008).

Regional drivers are often associated with the role of the atmosphere as a conduit between terrestrial and aquatic systems (Fig. 2). Hence we have drivers such as acid rain (Bouwman et al. 2002), nitrogen supply to the coastal ocean (Seitzinger \& Sanders 1997, Duce et al. 2008), and long-range delivery of fossil-fuel pollutants to offshore waters such as the western subtropical Atlantic (Sholkovitz et al. 2009). The interplay among MEDs may alter environmental heterogeneity and hence exacerbate the cumulative stress on biota (Fig. 2). However, in some cases, the interactions between local and global drivers may partially negate each other (Fig. 2).

The degree of environmental heterogeneity, and how it varies spatially (Helmuth et al. 2010) and temporally (Garcia Molinos \& Donohue 2010), determines rates and modes of acclimation or adaptation for the biota; for instance, highly variable environ-

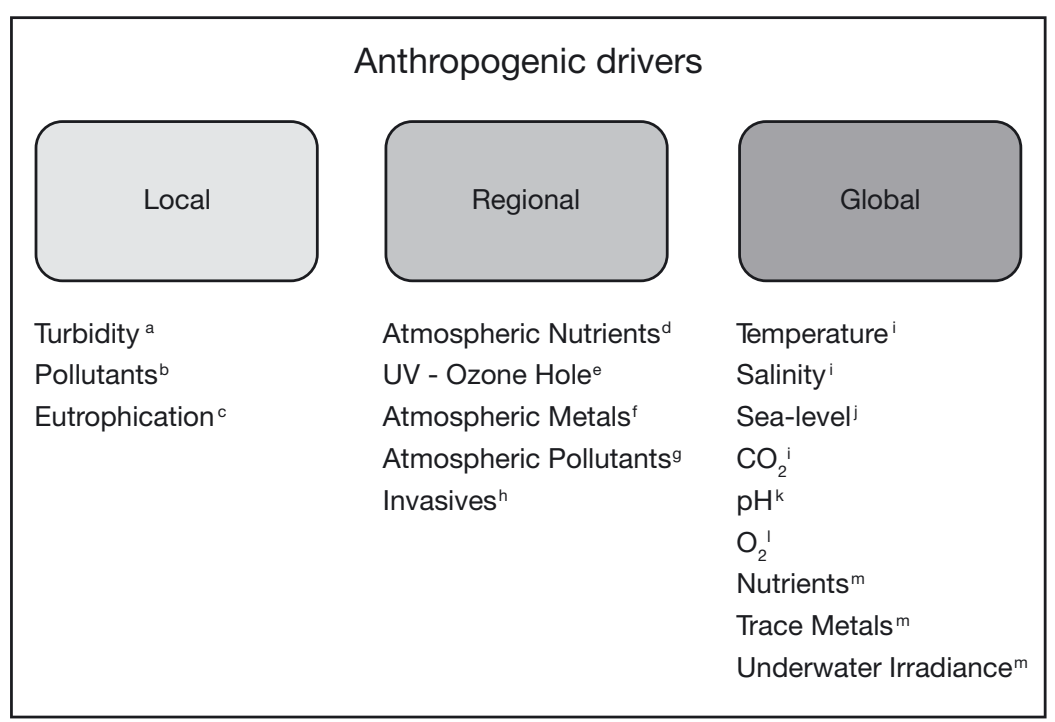

Fig. 2. The number of anthropogenic drivers increases when local, regional and global processes are considered together. The interplay among some drivers may serve to offset each other-for example, less upwelling nutrient supply versus more atmospheric nutrient supply to surface waters. Sources: ${ }^{\text {Boyd }}$ (2011), 'boney (2010), 'Seitzinger \& Sanders (1997), dDuce et al. (2008), ${ }^{\mathrm{e}}$ Cullen \& Neale (1997), ${ }^{\mathrm{f}}$ Paytan et al. (2009), ${ }^{\mathrm{g}}$ Sholkovitz et al. (2009); ${ }^{\mathrm{h}} \mathrm{Jaspers}$ et al. (2011), 'í Sarmiento et al. (2004), ${ }^{\mathrm{j}}$ Church \& White (2006); ${ }^{\mathrm{k}}$ Caldeira \&

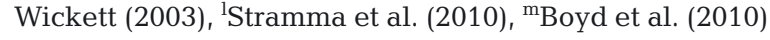


ments may place a premium on phenotypic plasticity. Another fundamental environmental difference between land and ocean is that the latter is dominated by microbes that are primarily free-drifting forms. These microbial communities comprise a very diverse community which may have built-in redundancy with respect to ecological and biogeochemical functions in a changing climate-the so-called insurance theory (Sogin et al. 2006). Such differences between systems in both environmental heterogeneity and ecosystem structure and function can make comparing trends in responses of the biota to altered MEDs problematic.

\section{Interactive environmental controls on ocean biota}

The control of primary producers by physical and chemical factors has historically been a major oceanographic research theme. The potentially growthlimiting environmental factors include nutrient supply, temperature, iron availability, and light. Early studies implicitly assumed that only a sole limiting factor was operative at a time, a concept known as the Liebig limitation (de Baar 1994). It is now recognized that multiple factors often simultaneously co-limit primary production (Arrigo 2005) and include iron and light (Sunda \& Huntsman 1997), and iron and silicate (Hutchins et al. 2002). In the last decade, studies have tested how MED's such as $\mathrm{pCO}_{2}$, warming, and changing iron availability may affect the base of pelagic food webs, and importantly, explicitly interpreting these multivariate interactions in a global change context (Fig. 3). Warming and iron-enrichment are shown to synergistically amplify the growth and productivity of antarctic phytoplankton communities (Rose et al. 2009a). Similarly, raising $\mathrm{CO}_{2}$ and temperature together strongly stimulates coccolithophore growth in the North Atlantic, but concurrently depresses calcification (Feng et al. 2009), confounding the wider biogeochemical implications.

Such interactive global change effects are less well-documented for higher trophic levels in pelagic systems, partly because large, active animals are often more difficult to manipulate experimentally than the phytoplankton. However, Rose et al. (2009b) observed that warming and OA together had a negative effect on microzooplankton grazer abundance in North Atlantic waters. Rossoll et al. (2012) found that diatom cells grown at high $\mathrm{pCO}_{2}$ inhibited growth and reproduction in copepod grazers, due to a severely reduced essential fatty acid content. Rosa \& Seibel (2008) demonstrated a negative interaction between OA, warming, and hypoxia, on the physiology and distribution of a top predator, the jumbo squid Dosidicus gigas. A major difference between biota at low and high trophic levels is that the former are subject to a wider range of MEDs (Fig. 3).

\section{Differential susceptibility to drivers across trophic levels}

Most research to date, on the effects of MEDs has focused on species or strains within a sole trophic level (Crain et al. 2008); for example OA studies have largely been conducted on calcifying primary producers (Gattuso \& Hansson 2011). Such findings need to be put into a wider context by addressing how the concurrent alteration of MEDs influences different trophic levels and ecosystem structure and functioning. This will introduce a further level of complexity to what are already challenging experiments; nevertheless, a continued emphasis only on one trophic level is inadequate to further our understanding of this topic at the ecosystem level (for

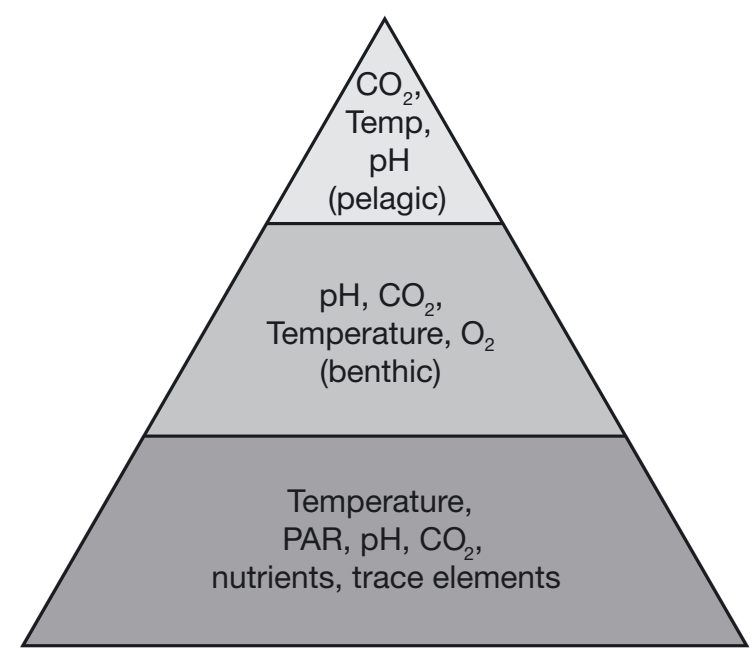

Fig. 3. The base of most food webs is influenced by a greater number of environmental conditions than those that influence the higher trophic levels, and thus by the complex interplay of many factors (Darling \& Côté 2008) under changing environmental conditions. Higher trophic levels (middle and apex of pyramid), in contrast, are embedded within a trophodynamic structure and may be vulnerable to the effects of differential susceptibilities of lower (prey) and higher (predators) trophic levels to altered environmental conditions. At higher trophic levels, pelagic organisms in relatively well-oxygenated waters may be affected by fewer environmental conditions (and their alteration under a changing climate) than benthic organisms. PAR: photosynthetically active radiation 
recent thematic reviews, see Brose et al. 2012 and Caron \& Hutchins in press).

Several studies have revealed differential susceptibility to MED's both within trophic levels (different species, e.g. coccolithophores, Langer et al. 2006; $\mathrm{N}_{2}$ fixers, Hutchins et al. unpubl.) and across trophic levels (e.g. temperate coastal calcifiers, Hurd et al. 2011). The ecological influence of such differential susceptibility amongst primary producers on higher trophic levels is difficult to gauge (Smayda 2011), whereas studies that include several trophic levels provide a more holistic view of the potential trophodynamic effects of a changing climate (Helmuth et al. 2010). Such differential vulnerability to change may result in counter-intuitive findings. For example, the ecological outcome of increased UV stress was enhanced primary productivity of benthic diatom communities, due to their grazers being more susceptible to UV damage (Bothwell et al. 1994). Marine ecologists can learn much from how entire ecosystems are perturbed across entire lakes (Carpenter et al. 2011), or in coastal waters using mesocosms (Riebesell 2004). Such studies enhance our understanding of the extent and nature of the 'ecological surprises' that may result from a changing climate (Lindenmayer et al. 2010). Other ecologically relevant topics which may influence or result from differential vulnerability across trophic levels, but which are beyond the scope of this Introduction, include: biodiversity and ecosystem dynamics (Vinebrooke et al. 2004); altered species distributions through migration (Parmesan et al. 1999) and invasion (Jaspers et al. 2011); and the nature of competitive versus facilitative relationships between organisms (Bulleri 2009).

\section{Present day approaches to multiple- driver research}

Current approaches focus mainly on perturbation studies in which MEDs are manipulated, e.g. temperature, $\mathrm{CO}_{2}$ and light (Feng et al. 2009). This complex approach arises from prior simpler studies in which a sole driver was manipulated, such as $\mathrm{pH}$ (Riebesell \& Tortell 2011). MED experiments require additional diagnostics (Fig. 1), relative to single-driver manipulations, to enhance the interpretative skills needed when several MEDs are being manipu- lated concurrently. Such studies are beginning to reveal the complex interplay and feedbacks between what have previously been considered to be relatively simple relationships between an individual driver and a particular physiological process, e.g. OA and phytoplankton calcification (Fig. 4).

Other studies are using the diagnostic power of '-omics' to probe changes resulting from such MED manipulations (Matallana-Surget et al. 2012) but so far they have mainly focused on the effects of chronic stress responses to toxins. A few such studies have been able to link multiple 'omics' - transcriptomics, proteomics or metabolomics via bioinformatics and modelling (Steinberg 2012). These provide a more complete picture of how environmental manipulations affect the biota, and also address issues such as acclimation to altered environmental conditions (Dyhrman et al. 2012). Other recent developments in manipulation experiments are studies conducted with microbes over many generations (i.e. years), as opposed to the brief span (weeks) normally employed in such experiments. Lohbeck et al. (2012) used a long-term approach to reveal that coccolithophores can adapt micro-evolutionarily to altered $\mathrm{CO}_{2} / \mathrm{pH}$ conditions. Another approach has focused on competitive exclusion experiments by comparing short-term (weeks) competitive dominance experiments using a 'naïve' natural dinoflagellate commu-

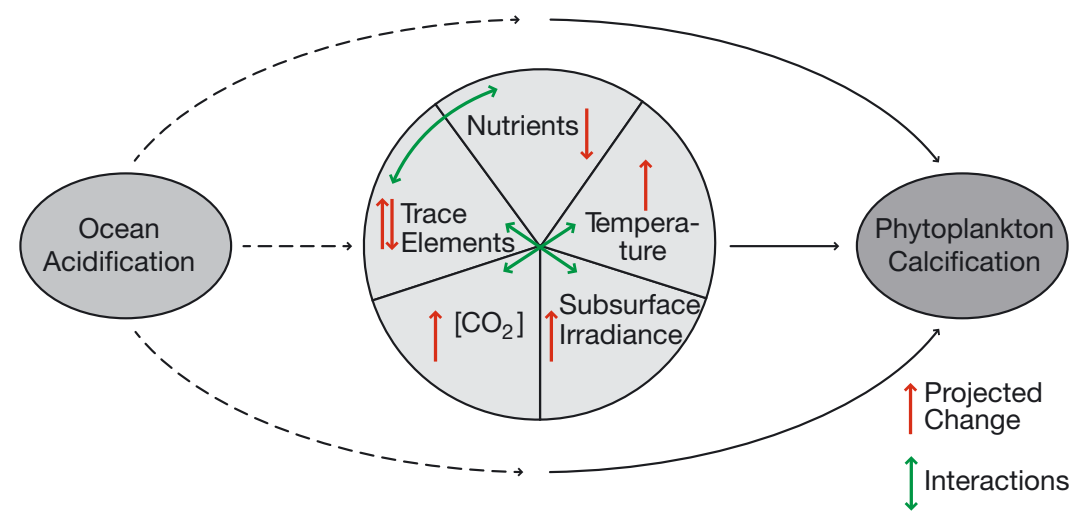

Fig. 4. Interplay between ocean acidification (OA) and phytoplankton calcification, when MEDs are considered. OA alters calcification (Riebesell et al. 2000), but under the MEDs scenario, OA influences some of the drivers (dashed lines), and additional drivers can influence calcification (solid lines). For example, OA affects nutrient and trace element availability (Royal Society 2005), and oceanic $\mathrm{CO}_{2}$ concentrations and speciation (Royal Society 2005), whereas other environmental drivers influence calcification $\left(\mathrm{CO}_{2}\right.$ : Royal Society 2005; temperature: Boyd et al. 2010; phosphate: Dyhrman et al. 2006, and light: Paasche 2001). Red arrows: the projected changes in ocean properties due to climate change (Boyd et al. 2010), green arrows: examples of synergistic and/or antagonistic effects of MEDs on the biota (Boyd et al. 2010). Confounding biological feedbacks on environmental factors (e.g. high $\mathrm{CO}_{2}$ may enhance $\mathrm{N}_{2}$ fixation and hence boost nutrient inventories, Hutchins et al. 2009) are not included in this schematic 
nity with the outcome of competition between the same species in analogous artificial communities after conditioning each species in clonal cultures under high $\mathrm{CO}_{2}$ conditions for $\sim 1 \mathrm{yr}$ (Tatters et al. in press). Below, in 'The future, new approaches', we examine how today's methods can be supplemented.

\section{Summary of the Theme Section}

For this Theme Section on 'Biological responses in an anthropogenically modified ocean', we have assembled a group of papers that examine how MEDs influence and affect key organisms and processes in the marine environment. The authors have taken on the difficult task of assembling and synthesizing the (often fragmentary) knowledge about how the effects of MEDs simultaneously in flux may differ from marine science's traditional reductionist emphasis on one factor at a time.

The coccolithophores have been at the forefront of both research advances and controversy in the study of the effects of OA. However, arguably less is known about their potential responses to MEDs than for any other phytoplankton group (Boyd et al. 2010). Raven \& Crawfurd (2012, this volume) tackle this topic by examining how MEDs affect this keystone functional group to global change. To do this, they draw on evidence from sources ranging from paleo-oceanography, through field-oriented process studies, to laboratory investigations using molecular and physiological methods. They conclude that more studies incorporating multivariate experimental designs and genetic methods of assessing the potential for adaptation are needed before we can fully understand the responses of the coccolithophores to MEDs.

Gao et al. (2012, this volume) address a topic that has, surprisingly, not been widely examined previously: How will rising $\mathrm{CO}_{2}$ and $\mathrm{OA}$ interact with solar radiation to affect phytoplankton? They review the literature on the individual effects of OA, warming, and changes in irradiance (i.e. photosynthetically active- and ultra violet-radiation). Next they describe the few studies that address interactions between these MEDs, and conclude with suggestions to move this field forward in the future.

Hoffmann et al. (2012, this volume) use the large body of research on trace element biogeochemistry from the last 20 years to predict future trends in the cycles of iron, zinc, copper, and other metals. They note that although single drivers affecting trace metal sources, speciation, solubility and biogeochemical cycling have been investigated to some extent, little information exists on the cumulative effects of a suite of MEDs comprising OA, warming, and hypoxia. They discuss the potential interplay between these MEDs in both high- and low-latitude regimes, and advocate the need for careful scrutiny and standardization of methodology in experiments combining both trace metal and MEDs.

Fu et al. (2012, this volume) consider the interactive effects of MEDs on environmentally destructive toxic and harmful algae. Due to worldwide human health impacts and economic damage caused by harmful algal bloom groups such as dinoflagellates, the effects of many individual factors including nutrients, light, temperature, $\mathrm{CO}_{2}$, and salinity have been examined in a well-established literature. However, oceanographers are just beginning to consider how coincident shifts in such MEDs may affect harmful algal blooms in the context of changing estuarine, coastal and oceanic environments.

Litchman et al. (2012, this volume) highlight the utility of the ecological niche concept in understanding the long-term responses of phytoplankton to global change. They make the case that trait-based niche models can be extended into multiple dimensions in order to describe the adaptation of algal functional groups to a changing matrix of MEDs. Development of such new trait-based models may have the ability to better predict the adaptive trajectories of key phytoplankton species in response to selection by MEDs, and Litchman et al. (2012) make a convincing case for their application to future studies in a variety of conceptual and experimental contexts.

A major question about global-change impacts is how the critical global biogeochemical processes may respond to simultaneous forcing from MEDs. Passow \& Carlson (2012, this volume) address this question for a key component of of the carbon cycle, the storage of carbon in the deep ocean by sinking biogenic particles. They argue that current knowledge gaps concerning the combined impacts of MEDs preclude firm predictions of whether oceanic carbon storage via the biological pump will increase or decrease in the future. They offer a way forward, though, by suggesting that better-constrained regional models of the biological pump can be integrated to obtain a holistic picture of global trends in future ocean carbon uptake..

The review by Pörtner (2012, this volume) uses the concept of oxygen and capacity dependent thermal tolerance (OCLTT) as a tool to understand the integrated responses of organisms to MEDs. Pörtner argues that OCLTT can be applied broadly enough 
to address the impacts of climate change and other anthropogenic drivers like pollution over scales ranging from physiological to ecological. The linkage between aerobic capacity and the thermal tolerance range of organisms in a variety of habitats may offer unique insights into their climate change responses as individuals and populations, as well as their roles in ocean ecosystems.

\section{The future-New approaches}

To begin to understand how an anthropogenically modified ocean affects the biota, we should learn from the last decade of studies into climate change effects on biota, in particular the research stemming from the OA research community, which to date has been the vanguard (Boyd 2011). OA research has advanced many facets of an acidifying ocean, but in comparison, the MED research represents a major logistical challenge (see Fig. 4), due to the numbers of permutations that must be explored for a wide range of species and trophic levels. There is a strong likelihood that individual labs will develop tangential research trajectories unless there is wellimplemented international coordination, e.g. the complex nature of carbonate chemistry and its manipulation resulted in many studies being conducted using different protocols (Hurd et al. 2009) and hence, obtaining a consensus view is difficult.

The production of a best practice guide, e.g. by OA researchers (Riebesell et al. 2010) is one way to tackle this major challenge for the MEDs community. A complementary approach is to use the resources of a relatively large scientific community to conduct experiments in a systematic manner, as has been done for some major projects (Human Microbiome Project Consortium 2012). Boyd et al. (unpubl.) have recently conducted such a community-wide study using a pre-agreed experimental protocol for a study (across 8 laboratories) on thermal reaction norms for phytoplankton species spanning the global ocean. There have been calls for similar community-wide initiatives to look at the ecological ramifications of climate change in the ocean (Nogués-Bravo \& Rahbek et al. 2011).

Experimental evolutionary biology is another potentially powerful tool in MED research to better tackle issues such as acclimation (plasticity) versus adaptation to global change in aquatic organisms (Piersma \& Drent 2003). This tool is increasingly being applied to understand long-term responses of organisms to selection by single factors such as warming (Huertas et al. 2011) and $\mathrm{CO}_{2}$ (Collins \& Bell 2004). This new oceanographic research emphasis by experimental environmental biology has, however, yet to attempt to address multivariate global change issues. The difficulties of understanding the short-term physiological responses of marine species to multiple drivers relative to single drivers pale in comparison to the bewildering complexities of disentangling long-term evolutionary responses to many simultaneous changes to MEDs. Rigorous attribution of observed adaptive trends with their own synergisms and antagonisms, and prediction of the consequences for organismal reproductive and competitive success, will require marine global-change scientists to make a quantum leap forward conceptually and logistically. Fortunately, a new toolbox of genomic, transcriptomic, and proteomic methods (Dyhrman et al. 2012, Steinberg 2012) is revolutionising our science by allowing us to capture and understand holistic organismal responses to a changing ocean.

Climate-change modelling approaches will also be powerful tools to inform the experimentalists of the zones in which the overlap of local, regional and global anthropogenic change will be particularly large. Specialised modelling of ecosystem structure and interactions, cellular physiology, and evolutionary adaptation to change will also play an essential role in directing research. Close collaborations between experimentalists, observationalists and biogeochemical modelers can greatly improve our predictions of the global (e.g. Hutchins et al. unpubl.) and regional (Boyd et al. 2011) consequences of MEDs.

For MED research on phytoplankton, there is the issue of the thousands of phytoplankton species (Smayda 2011), and strains (Iglesias-Rodriguez et al. 2006), and the impossibility of investigating how each will respond to complex patterns of environmental change. OA research has revealed that different coccolithophore species have markedly different responses to lowering $\mathrm{pH}$ (Langer et al. 2006), as do strains of some of these calcifying species, such as Emiliania huxleyi (Langer et al. 2009). Strain-specific responses are also documented for $\mathrm{CO}_{2}$ effects on $\mathrm{N}_{2}$-fixing cyanobacteria Trichodesmium and Crocosphaera (Hutchins et al. unpubl.), as well as on the widely distributed eukaryotic picoplankton species Ostreococcus tauri (Schaum et al. unpubl.). Taxonspecific differences in the ability to adapt to warming have been demonstrated across a range of phytoplankton species (Huertas et al. 2011). These findings point to the difficulty in selecting a phyto- 
plankton functional type, as has been the approach traditionally used in biogeochemical models (Hood et al. 2006). Alternatively, these results may indicate that there is sufficient redundancy across the phytoplankton assemblage that will make the assemblage malleable to such complex patterns of environmental change. However, the ecological and biogeochemical ramifications of such redundancy-for example a small calcifier or $\mathrm{N}$-fixer being replaced by a larger one-are issues that still need to be resolved (Joint et al. 2011).

One approach to circumvent the 'paralysis of the plankton' in research terms would be to examine a subset of species/strains (or in the case of microbes, using metabolic functions, Dinsdale et al. (2008), Burke et al. (2011)), across a range of biomes to explore how such functionality responds to environmental change This has been attempted for the higher trophic levels with respect to temperature by Pörtner \& Knust (2007) and Helmuth et al. (2010). Such a unifying theory might be built around the physicochemical constraints that impose as to how far cell physiology (for example diffusion rates of nutrients, Kiørboe 2008), phytoplankton functional traits (Litchman et al. 2012) or cell biochemistry (Makarieva et al. 2008) can be altered by a complex matrix of changing conditions. These approaches would link well with the outputs from climate change models. By thoughtfully debating and subsequently adopting such research guide- and time-lines, in the coming decade a coordinated and integrated ocean global change research community should be able to significantly advance these themes studying the responses of the biota in an anthropogenically modified ocean.

Acknowledgements. The Ministry of Science and Innovation New Zealand is acknowledged for core funding to P.W.B. for research into Coasts and Oceans, and the U.S. National Science Foundation for grants 0722337, 0962309, 1043748 and 1143760 to D.A.H.

\section{LITERATURE CITED}

Bothwell ML, Sherbot DMJ, Pollock CM (1994) Ecosystem response to solar ultraviolet-B radiation: influence of trophic level interactions. Science 265:97-100

Bouwman AF, Van Vuuren DP, Derwent RG, Posch M (2002) A global analysis of acidification and eutrophication of terrestrial ecosystems. Water Air Soil Pollut 141:349-382

Boyd PW (2011) Beyond ocean acidification. Nat Geosci 4: 273-274

Boyd PW, Doney SC (2002) Modelling regional responses by marine pelagic ecosystems to global climate change. Geophys Res Lett 29:1806-1810
Boyd PW, Doney SC, Strzepek R, Dusenberry J, Lindsay K, Fung I (2008) Climate-mediated changes to mixed layer properties in the Southern Ocean: assessing the phytoplankton response. Biogeosciences 5:847-864

> Boyd PW, Strzepek R, Fu FX, Hutchins DA (2010) Environmental control of open ocean phytoplankton groups: now and in the future. Limnol Oceanogr 55:1353-1376

Boyd PW, Law C, Doney S (2011) Commentary: A climate change atlas for the ocean. Oceanography 24:13-16

Breitburg DL, Baxter JW, Hatfield CA, Howarth RW, Jones CG, Lovett GM, Wigand C (1998) Understanding effects of multiple stressors: ideas and challenges. In: Pace ML, Groffman PM (eds) Successes, limitations, and frontiers in ecosystem science, Chapt 17. Springer Verlag, New York, NY, p 416-431

Breitburg DL, Seitzinger SP Sanders JG (1999) Effects of multiple stressors in marine and freshwater systems. Limnol Oceanogr 44(3):Preface

Brose U, Dunne JA, Montoya JM, Petchey OL, Schneider FD, Jacob U (2012) Introduction: Climate change in sizestructured ecosystems. Phil Trans R Soc B 367:2903-2912

Bulleri F (2009) Facilitation research in marine systems: state of the art, emerging patterns and insights for future developments. J Ecol 97:1121-1130

Burke C, Steinberg P, Rusch D, Kjellberg S, Thomas T (2011) Bacterial community assembly based on functional genes rather than species. Proc Natl Acad Sci USA 108: 14288-14293

Caldeira K, Wickett ME (2003) Oceanography: anthropogenic carbon and ocean $\mathrm{pH}$. Nature 425:365

Calow P (1989) Proximate and ultimate responses to stress in biological systems. Biol J Linn Soc 37:173-181

Caron DA, Hutchins DA (in press) The effects of changing climate on microzooplankton community structure and grazing: drivers, predictions and knowledge gaps. J Plankton Res

Carpenter SR, Cole JJ, Pace ML, Batt R and others (2011) Early warnings of regime shifts: a whole-ecosystem experiment. Science 332:1079-1082

Church JA, White NJ (2006) A 20th century acceleration in global sea-level rise. Geophys Res Lett 33:L01602, doi: 10.1029/2005GL024826

> Collins S, Bell B (2004) Phenotypic consequences of 1,000 generations of selection at elevated $\mathrm{CO}_{2}$ in a green alga. Nature 431:566-569

Crain CM, Kroeker K, Halpern BS (2008) Interactive and cumulative effects of multiple human stressors in marine systems. Ecol Lett 11:1304-1315

> Cullen JJ, Neale PJ (1997) Effect of ultraviolet radiation on short-term photosynthesis of natural phytoplankton. Photochem Photobiol 65:264-266

> Darling ES, Côté IM (2008) Quantifying the evidence for ecological synergies. Ecol Lett 11:1278-1286

$>$ De Baar HJW (1994) Von Liebig law of the minimum and plankton ecology (1899-1991). Prog Oceanogr 33:347-386

Dickson AG (1992) The development of the alkalinity concept in marine chemistry. Mar Chem 40:49-63

Didham RK, Tykianakis JM, Gemmell NJ, Rand TA, Ewers RM (2007) Interactive effects of habitat modification and species invasion on native species decline. Trends Ecol Evol 22:489-496

> Dinsdale EA, Edwards RA, Hall D, Angly F and others (2008) Functional metagenomic profiling of nine biomes. Nature 452:629-632

Doney SC (2010) The growing human footprint on coastal and open ocean biogeochemistry. Science 328:1512-1516 
Dore JE, Lukas R, Sadler DW, Church MJ, Karl DM (2009) Physical and biogeochemical modulation of ocean acidification in the central North Pacific. Proc Natl Acad Sci USA 106:12235-12240

> Duce RA, LaRoche J, Altieri K, Arrigo KR and others (2008) Impacts of atmospheric anthropogenic nitrogen on the open ocean. Science 320:893-897

Dyhrman ST, Haley ST, Birkeland SR, Wurch LL and others (2006) Long serial analysis of gene expression for gene discovery and transcriptome profiling in the widespread marine coccolithophore Emiliania huxleyi. Appl Environ Microbiol 72:252-260

Dyhrman ST, Jenkins BD, Rynearson TA, Saito MA and others (2012) The transcriptome and proteome of the diatom Thalassiosira pseudonana reveal a diverse phosphorus stress response. PLoS ONE 7:e33768.

Falkowski PG, LaRoche J (1991) Acclimation to spectral irradiance in algae. J Phycol 27:8-14

Feng Y, Hare CE, Leblanc K, Rose JM and others (2009) Effects of increased $\mathrm{pCO}_{2}$ and temperature on the North Atlantic spring bloom. I. The phytoplankton community and biogeochemical response. Mar Ecol Prog Ser 388: 13-25

> Folt CL, Chen CY, Moore MV, Burnaford J (1999) Synergism and antagonism among multiple stressors. Limnol Oceanogr 44:864-877

Fu FX, Mulholland MR, Garcia N, Beck A and others (2008) Interactions between changing $\mathrm{pCO}_{2}, \mathrm{~N}_{2}$ fixation, and Fe limitation in the marine unicellular cyanobacterium Crocosphaera. Limnol Oceanogr 53:2472-2484

Fu FX, Tatters AO, Hutchins DA (2012) Global change and the future of harmful algal blooms in the ocean. Mar Ecol Prog Ser 470:207-233

- Gao K, Helbling EW, Häder DP, Hutchins DA (2012) Responses of marine primary producers to interactions between ocean acidification, solar radiation, and warming. Mar Ecol Prog Ser 470:167-189

Garcia Molinos J, Donohue I (2010) Interactions among temporal patterns determine the effects of multiple stressors. Ecol Appl 20:1794-1800

Gattuso JP, Hansson L (2011) Ocean acidification. Oxford University Press, Oxford

Gruber N (2011) Warming up, turning sour, losing breath: ocean biogeochemistry under global change. Philos Trans R Soc A 369:1980-1996

Hare CE, Leblanc K, DiTullio GR, Kudela RM and others (2007) Consequences of increased temperature and $\mathrm{CO}_{2}$ for phytoplankton community structure in the Bering Sea. Mar Ecol Prog Ser 352:9-16

> Helmuth B, Broitman BR, Yamane L, Gilman SE, Mach K, Mislan KAS, Denny MW (2010) Organismal climatology: analyzing environmental variability at scales relevant to physiological stress. J Exp Biol 213:995-1003

Hofmann GE, Smith JE, Johnson KS, Send U and others (2011) High-frequency dynamics of ocean pH: a multiecosystem comparison. Plos One, 6:e28983.

> Hoffmann L, Breitbak E, Boyd PW, Hunter KA (2012) Influence of ocean warming and acidification on trace metal biogeochemistry. Mar Ecol Prog Ser 470:191-205

> Hood RR, Laws EA, Armstrong RA, Bates NR and others (2006) Pelagic functional group modeling: progress, challenges and prospects. Deep-Sea Res II 53:459-512

Huertas IE, Rouco M, López-Rodas V, Costas E (2011) Warming will affect phytoplankton differently: evidence through a mechanistic approach. Proc Biol Sci 278: 3534-3543
Human Microbiome Project Consortium (2012) Structure, function and diversity of the healthy human microbiome. Nature 486:201-214

> Hurd CL, Hepburn CD, Currie KI, Raven JA, Hunter KA (2009) Testing the effects of ocean acidification on algal metabolism: considerations for experimental designs. J Phycol 45:1236-1251

Hurd CL, Cornwall CE, Currie K, Hepburn CD, McGraw CM, Hunter KA, Boyd PW (2011) Metabolically induced $\mathrm{pH}$ fluctuations by some coastal calcifiers exceed projected 22nd century ocean acidification: a mechanism for differential susceptibility? Glob Change Biol 17: 3254-3262

Hutchins DA, Hare CE, Weaver RS, Zhang Y and others (2002) Phytoplankton iron limitation in the Humboldt Current and Peru Upwelling. Limnol Oceanogr 47:997-1011

> Hutchins DA, Fu FX, Zhang Y, Warner ME and others (2007) $\mathrm{CO}_{2}$ control of Trichodesmium $\mathrm{N}_{2}$ fixation, photosynthesis, growth rates, and elemental ratios: implications for past, present, and future ocean biogeochemistry. Limnol Oceanogr 52:1293-1304

> Hutchins DA, Mulholland MR, Fu FX (2009) Nutrient cycles and marine microbes in a $\mathrm{CO}_{2}$-enriched ocean. Oceanography 22:128-145

Iglesias-Rodriguez MD, Schofield OM, Batley J, Medlin LK, Hayes PK (2006) Intraspecific genetic diversity in the marine coccolithophore Emiliania huxleyi (Prymnesiophyceae): the use of microsatellite analysis in marine phytoplankton population studies. J Phycol 42:526-536

Jaspers C, Titelman J, Hansson LJ, Haraldsson M, Ditlefsend CR (2011) The invasive ctenophore Mnemiopsis leidyi poses no direct threat to Baltic cod eggs and larvae. Limnol Oceanogr 56:431-439

Joint I, Doney SC, Karl DM (2011) Will ocean acidification affect marine microbes? ISME J 5:1-7

Kiørboe T (2008) A mechanistic approach to plankton ecology. Princeton University Press, Princeton, NJ

> Langer G, Geisen M, Baumann KH, Klas J, Riebesell U, Thoms S, Young JR (2006) Species-specific responses of calcifying algae to changing seawater carbonate chemistry. Geochem Geophys Geosyst 7:Q09006, doi:10.1029/ 2005GC001227

> Langer G, Nehrke G, Probert I, Ly J, Ziveri P (2009) Strainspecific responses of Emiliania huxleyi to changing seawater carbonate chemistry. Biogeosciences 6:2637-2646

Letunic I, Yamada T, Kanehisa M, Bork P (2008) iPath: interactive exploration of biochemical pathways and networks. Trends Biochem Sci 33:101-103

Lindenmayer DB, Likens GE, Krebs CJ, Hobbs RJ (2010) Improved probability of detection of ecological 'surprises'. Proc Natl Acad Sci USA 107:21957-21962

Litchman E, Klausmeier CA, Miller JR, Schofield OM, Falkowski PG (2006) Multinutrient, multi-group model of present and future oceanic phytoplankton communities. Biogeosciences 3:585-606. Available at www.biogeosciences.net/3/585/2006/

> Litchman E, Edwards KF, Klausmeier CA, Thomas MK (2012) Phytoplankton niches, traits and eco-evolutionary responses to global environmental change. Mar Ecol Prog Ser 470:235-248

Lohbeck KT, Riebesell U, Reusch TBH (2012) Adaptive evolution of a key phytoplankton species to ocean acidification. Nat Geosci 5:346-351

$>$ Lough JM, Barnes DJ (2000) Environmental controls on growth of the massive coral Porites. J Exp Mar Biol Ecol 245:225-243 
Makarieva AM, Gorshkov VG, Li BL, Chown SL, Reich PB, Gavrilov VM (2008) Mean mass-specific metabolic rates are strikingly similar across life's major domains: evidence for life's metabolic optimum. Proc Natl Acad Sci USA 105:16994-16999

Matallana-Surget S, Joux F, Wattiez R, Lebaron P (2012) Proteome analysis of the UVB-resistant marine bacterium Photobacterium angustum S14. PLoS ONE 7: e42299

Nogales B, Lanfranconi MP, Pina-Villalonga JM, Bosch R (2011) Anthropogenic perturbations in marine microbial communities. FEMS Microbiol Rev 35:275-298

- Nogués-Bravo D, Rahbek C (2011) Communities under climate change. Science 334:1070-1071

Paasche E (2001) A review of the coccolithophorid Emiliania huxleyi (Prymnesiophyceae), with particular reference to growth, coccolith formation, and calcification-photosynthesis interactions. Phycologia 40:503-529

Parmesan C, Ryrholm N, Stefanescu C, Hill JK and others (1999) Poleward shifts in geographical ranges of butterfly species associated with regional warming. Nature 399:579-583

Passow U, Carlson,C (2012) The biological pump in a high $\mathrm{CO}_{2}$ world. Mar Ecol Prog Ser 470:249-271

Paytan A, Mackey KRM, Chen Y, Limac ID and others (2009). Toxicity of atmospheric aerosols on marine phytoplankton. Proc Natl Acad Sci 106:4601-4605

> Piersma T, Drent J (2003) Phenotypic flexibility and the evolution of organismal design. Trends Ecol Evol 18:228-233

> Pörtner H (2012) Integrating climate-related stressor effects on marine organisms: unifying principles linking molecule to ecosystem-level changes. Mar Ecol Prog Ser 470: 273-290

Pörtner HO, Knust R (2007) Climate change affects marine fishes through the oxygen limitation of thermal tolerance. Science 315:95-97

Raven JA, Crawfurd K (2012) Environmental controls on coccolithophore calcification. Mar Ecol Prog Ser 470: 137-166

Reusch TBH, Boyd PW (in press) Oceanography-a novel research area for evolutionary biologists. Evolution

Riebesell U (2004) Effects of $\mathrm{CO}_{2}$ enrichment on marine phytoplankton. J Oceanogr 60:719-729

Riebesell U, Tortell PD (2011) Effects of ocean acidification on pelagic organisms and ecosystems. In: Gattuso JP, Hansson L. Ocean acidification. Oxford University Press, Oxford

Riebesell U, Zondervan I, Rost B, Tortell PD, Zeebe RE, Morel FMM (2000) Reduced calcification of marine plankton in response to increased atmospheric $\mathrm{CO}_{2}$. Nature 407:364-367

Riebesell U, Fabry VJ, Hansson L, Gattuso JP (eds) (2010) Guide to best practices for ocean acidification research and data reporting. Publications Office of the European Union, Luxembourg

Roemmich D, Gould WJ, Gilson J (2012) 135 years of global ocean warming between the Challenger expedition and the Argo Programme. Nature Clim Change 2:425-428

Rosa R, Seibel BA (2008) Synergistic effects of climaterelated variables suggest future physiological impairment in a top oceanic predator. Proc Natl Acad Sci USA
105:20776-20780

Rose JM, Feng Y, DiTullio GR, Dunbar R and others (2009a) Synergistic effects of iron and temperature on antarctic phytoplankton and microzooplankton assemblages. Biogeosciences 6:3131-3147

Rose JM, Feng Y, Gobler CJ, Gutierrez R, Hare CE, Leblanc $\mathrm{K}$, Hutchins DA (2009b) Effects of increased $\mathrm{pCO}_{2}$ and temperature on the North Atlantic spring bloom. II. Microzooplankton abundance and grazing. Mar Ecol Prog Ser 388:27-40

Rossoll D, Bermúdez R, Hauss H, Schulz KG, Riebesell U, Sommer U, Winder M (2012) Ocean acidificationinduced food quality deterioration constrains trophic transfer. PLoS ONE 7:e34737

Royal Society (2005) Ocean acidification due to increasing atmospheric carbon dioxide. Policy document 12/05, The Royal Society, London

> Sarmiento JL, Slater R, Barber R, Bopp L and others (2004) Response of ocean ecosystems to climate warming. Global Biogeochem Cycles 18:GB3003, doi:10.1029/2003 GB002134

Schiel DR, Steinbeck JR, Foster MS (2004) Ten years of induced ocean warming causes comprehensive changes in marine benthic communities. Ecology 85:1833-1839

Seitzinger SP, Sanders RW (1997) Contribution of dissolved organic nitrogen from rivers to estuarine eutrophication. Mar Ecol Prog Ser 159:1-12

> Sholkovitz ER, Sedwick PN, Church TM (2009) Influence of anthropogenic combustion emissions on the deposition of soluble aerosol iron to the ocean: empirical estimates for island sites in the North Atlantic. Geochim Cosmochim Acta 73:3981-4003

> Smayda TJ (2011) Cryptic planktonic diatom challenges phytoplankton ecologists. Proc Natl Acad Sci USA 108:4269-4270

> Sogin ML, Morrison HG, Huber JA, Welch DM and others (2006) Microbial diversity in the deep sea and the underexplored 'rare biosphere'. Proc Natl Acad Sci USA 103: $12115-12120$

Steinberg CEW (2012) The actual response: ecological proteomics and metabolomics. In: Steinberg CEW (ed) Stress ecology: environmental stress as ecological driving force and key player in evolution. Springer, Heidelberg, p 241-278

Stramma L, Schmidtko S, Levin LA, Johnson GC (2010) Ocean oxygen minima expansions and their biological impacts. Deep-Sea Res I 57:587-595

Sunda WG, Huntsman SA (1997) Interrelated influence of iron, light, and cell size on growth of marine phytoplankton. Nature 390:389-392

Tatters AO, Schnetzer A, Fu FX, Lie AYA, Caron DA, Hutchins DA (in press) Short- versus long-term responses to changing $\mathrm{CO}_{2}$ in a coastal dinoflagellate bloom: Implications for interspecific competitive interactions and community structure. Evolution

Toupin L (2005) Freshwater habitats: life in freshwater ecosystems. Turtleback Books, St. Louis, MO

Vinebrooke RD, Cottingham KL, Norberg J, Scheffer M, Dodson SI, Maberly SC, Sommer U (2004) Impacts of multiple stressors on biodiversity and ecosystem functioning: the role of species co-tolerance. Oikos 104:451-457 